\title{
Dosimetric Evaluation of Two Different Total Body Irradiaton Techniques Using Eclips Treatment Plannig System
}

\author{
Íki Farkli Tüm Vücut Işinlamasi Tekniğinin Eclipse \\ Tedavi Planlama Sistemi Kullanılarak Dozimetrik Olarak \\ Değerlendirilmesi
}

Serap Catli Dinc ${ }^{1}$,

Niyazi Volkan Demircan ${ }^{1}$

Aybala Nur Turan ${ }^{1}$,

Muhammed Ertugrul Senturk ${ }^{1}$

Eray Karahacioglu ${ }^{1}$,

Huseyin Bora ${ }^{1}$

'Gazi University, Faculty of Medicine, Department of Radiation Oncology, Ankara,Turkey

Geliş Tarihi/Received: 22 April 2019 Kabul Tarihi/Accepted: 7 July 2019

Address correspondence to: Serap Catli Dinc, Gazi University, Faculty of Medicine, Department of Radiation Oncology, Ankara,Turkey

e-mail: serapcatli@hotmail.com

ORCID

Serap Catli Dinc

https://orcid.org/0000-0003-1121-3119

N. Volkan Demircan

https://orcid.org/0000-0001-9632-180x Aybala Nur Turan

https://orcid.org/0000-0001-8373-113x

M. Ertuğrul Senturk

https://orcid.org/0000-0002-4074-3277

Eray Karahacioglu

https://orcid.org/0000-0001-9207-1639

Huseyin Bora

https://orcid.org/0000-0002-9825-1638

\section{INTRODUCTION}

Total body irradiation (TBI) is a common method teknik

\section{Abstract} bilateral technique

\begin{abstract}
Öz
Amaç: Bu çalışma, Eclipse tedavi planlama sistemi kullanılarak, genişletilmiş kaynak cilt mesafesindeki iki tüm vücut ışınlama tekniği (TBI) için risk altındaki organ dozlarını karşılaştırmaktadır. Hastalar ve Yöntem: Bilateral TBI uygulanan 20 hasta için geriye dönük olarak AP-PA (anteroposterior) tekniği ile 3D tedavi planları olușturuldu. Her hasta için, doz hacim histogramları (DVH) oluşturmak ve 3D doz hacmi dağılımlarını incelemek amacıyla tüm vücut, böbrekler, akciğerler, tiroid ve karaciğer konturlaması yapıldı. Tiroid, akciğer, böbrek, karaciğer ve tüm vücut ortalama dozları, tedavi hacimleri ve \% 2 hacmin aldığı maksimum dozları (D2) doz volume histogramından hesaplandı ve SPSS dosyasına aktarıldı. Parametrik olmayan Wilcoxon testi, iki teknik için doz değerlerini karşılaştırmak amacıyla kullanıldı.

Bulgular: Lateral pozisyonda TBI uygulanan hastaların tiroid bezi ortalama dozları, AP pozisyona göre anlamlı olarak düşük gözlendi ( 11.98 and $12.64 \mathrm{~Gy}, \mathrm{p}=0.21$ ). Akciğer dozları açısından iki teknik arasında istatiksel olarak anlamlı fark gözlenmedi. Çünkü, her iki teknikte de akciğerler kurşun bloklarla korundu. Karaciğer ve böbrek ortalama dozları lateral planlamada daha düşük bulundu (sırasıyla $p=0.002$ ve $p=0.004)$. Karaciğer D2 dozları ise AP planlama tekniğinde daha düşük saptandı $(p=0.032)$. Her iki teknik arasındaki sıcak alanların karşılaştırılmasında ise çok belirgin şekilde lateral pozisyon üstün bulundu $(p<0.0001)$

Sonuç: Bu çalışmada, sıcak noktaları önlemek için bilateral pozisyonun AP-PA pozisyonundan daha üstün olduğu gözlendi. AP pozisyonda vücudun girintili çıkıntılı yapısını tolere etmek daha zor olmaktadır. Ek olarak, organların (karaciğer,böbrek,tiroid) doz dağılımları karşılaştırıldığında, lateral pozisyonda sonuçların istatistiksel olarak daha iyi çıktığı görüldü. Lateral pozisyon, daha homojen doz dağılımı ve daha iyi kalitede planlama yapma açısından avantaj sağlamaktadır.
\end{abstract}

Anahtar Kelimeler: Tüm vücut ışınlaması, tedavi planlama sistemi, doz dağılımı, AP-PA tekniği, bilateral

Aim: This study compares the organ doses at risk by using the Eclipse treatment planning system for two common total body irradiation techniques (TBI) at extended source skin distance.

Patients and Methods: 3D treatment plans with AP-PA (anteroposterior) technique were created retrospectively for 20 patients treated bilateral TBI. For each patient, the whole body, kidneys, lungs, thyroid and liver were contoured to create (DVH) dose volume histograms and examine 3D dose volume distributions. The mean doses of thyroid, lung, kidney, liver, whole body and treatment volumes and the maximum doses of $2 \%$ volumes (D2) were calculated from the dose volume histogram and transferred to the SPSS file. The non-parametric Wilcoxon test was used to compare the dose values for two techniques. Results: Thyroid gland mean doses were significantly lower in lateral technique (11.98 and 12.64 Gy, $p=0.21$ ). It was observed no statistically dose difference between the two techniques in terms of lung doses. Since, the lungs were protected by lead blocks in both of two techniques. The mean doses of live and kidney were lower in the lateral TBI technique $(p=0.002$ and $p=0.004$, respectively). D2 doses of liver were lower in AP-PA planning technique $(p=0.032)$. In comparison of the hot points between the two techniques, the lateral position was significantly superior $(p<0.0001)$

Conclusions: In present study, it was observed that the bilateral position was superior to the AP-PA position in order to prevent the hot spots. In the AP-PA position, it is more difficult to tolerate the body irregularities. Additionally, when comparing the dose distributions of the organs (liver, kidney, thyroid), it was seen that the results were statistically better in the lateral position. The lateral position provides an advantage in terms of more homogenous dose distribution and better quality planning.

Key words: Total body irradiation, treatment planning system, dose distribution, AP-PA technique
Cite this article as: Catli Dinc $S$ Demircan NV, Turan AN, Senturk ME, Karahacioglu E, Bora H. Dosimetic Evaluation Of Two Different Total Body Irradiaton Techniques Using Eclips Treatment Plannig System. Selcuk Med J 2020;36(1): 33-38 used in allogeneic stem cell transplantation in leukemia patients. TBI serves to destroy recipients Disclosure: None of the authors has a financial interest in any of the
products, devices, or drugs mentioned in this article. The research was
not sponsored by an outside organization. All authors have agreed to allow
full access to the primary data and to allow the journal to review the data
if requested. 
bone marrow cells (myeloablative) and to reduce donor stem cell rejection (immunosuppression). The main objective of whole body irradiation is to destroy all white blood cell precursors before healthy bone marrow transplantation. It is part of the preparation regime of bone marrow transplantation. TBI treatment has started at 1932 (1). Treatment techniques varied from treatment machine to treatment machine and from clinic to clinic. Different clinics may have different methods of patient setup (2). Although these techniques are different in the details, they are all aimed to give a uniform dose to the patient body.

TBI is mostly AP-PA applied from an extended source skin distance (SSD) to patients while they are lying down or standing. SSD and the field size are arranged to $400 \mathrm{~cm}$ and collimators are arranged to 45 degrees. Lungs and previously irradiated fields are protected via lead blocks. Physical treatment planning for $\mathrm{TBI}$ has traditionally been performed using a manual point dose calculation AP-PA approach. However, there are drawbacks of manual dose calculation. A homogeneous dose distribution is difficult and time consuming job. Additionally, the 3D dose distribution cannot be estimated. When the total body is irradiated, it is important to ensure a uniform dose distribution. As a result of untidy body contour and density variations among the tissues, the absorbed dose in the patients are significantly affected, and then it is difficult to ensure a uniform dose distribution on the patient.

When performing TBI irradiation, the determination of critical organs and the doses play an important role in increasing the effectiveness of treatment. To avoid more severe damage, or even a possible mortality, it is important to ensure homogeneous dose distribution. Prodromal symptoms like nausea, vomiting, somnolence and fatigue can be seen related to TBI. Long-term and more serious complications of TBI are cataract, cognitive function disorders, endocrine pathologies, interstitial pneumonia, pulmonary fibrosis, hepatic and renal dysfunction, growing retardation, infertility and secondary cancers. However, only pneumonia is the dose limiting complication of TBI (3). Therefore, the treatment planning system is required for the dose calculation of TBI. Treatment planning systems are an accurate method used to calculate the dose distribution within the patient (4). Although TBI techniques have been used in clinics for many years, there is not any study about the dosimetric results of treatment techniques. In present study, it is aimed to evaluate the doses of organs at risk for two TBI treatment ( patient standing-AP-PA or lying down) techniques using with the Eclipse Treatment Planning.

\section{PATIENTS AND METHODS}

TBI is performed using bilateral beams at an extended SSD distance $(4 \mathrm{~m})$ in our institution. All treatments were delivered on a Saturne 43 linear accelerator with a $10 \mathrm{MV}$ photon beam at $40 \times 40 \mathrm{~cm}^{2}$ field size, 90 o gantry angle and $45^{\circ}$ collimator angle. The patients are immobilized in supine position, it's tied on his belly and its feet drawn toward its stomach. The treatment fields were centered at the height of the umbilicus. The reference point was defined at umbilicus. For a consecutive three days, a standard dose of 200 (cGy) has been performed twice daily for TBI. In AP-PA technique, the patient stands on a panel in front of the gantry (90o) at extended SSD distance (4 m). Lungs were shielded during the bilateral and AP-PA irradiation (Figure 1). The lung blocks were fixed by a plastic tray. How many fractions of the lungs would be blocked was determined in the treatment planning system. The position of the shielding blocks was controlled by megavolt portal films (Figure 2).

The rice bags were used as bolus material to provide dose homogeneity in the head and neck and lower extremities which were thinner than the median line of the body. 3-D treatment plannings were created using Eclipse Treatment Planning System (TPS, 7.5 version) (VARIAN). The patients were scanned using computed tomography (SIEMENS) and the images were electronically entered into the Eclipse TPS. For each patient, the whole body, kidneys, lungs, thyroid and liver were contoured to create (DVH) dose volume histograms and examine 3D dose volume distributions. The pencil beam convolution algorithm

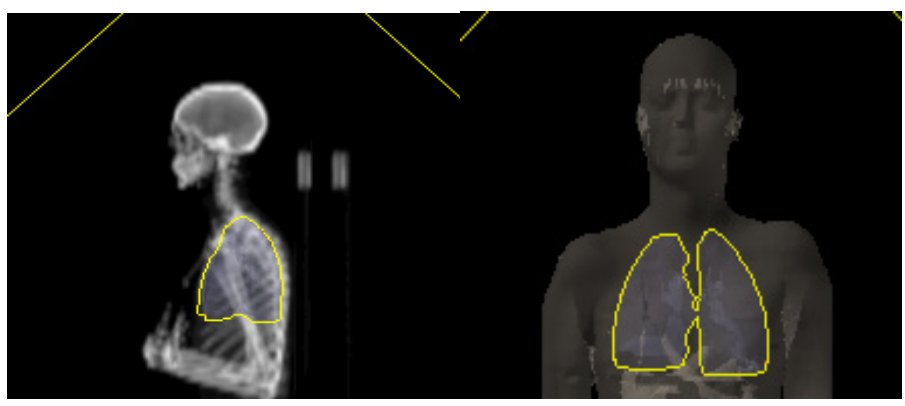

Figure 1. During TBI, the position of the bilateral and AP-PA lung blocks 


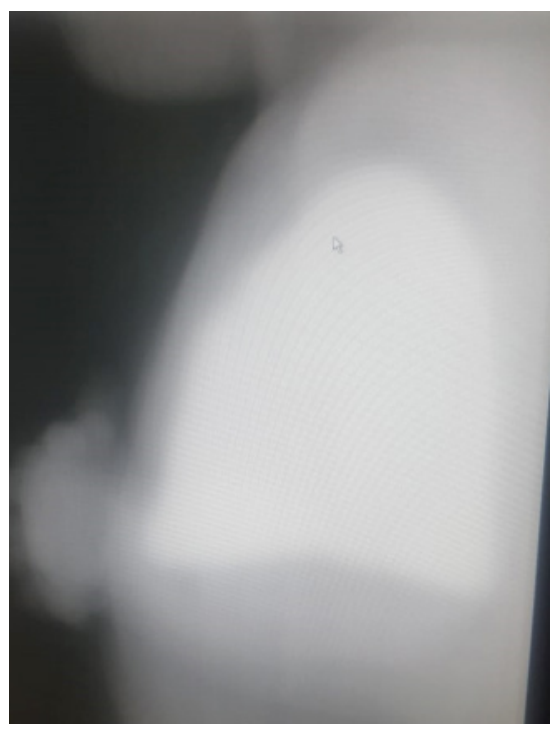

Figure 2. MV portal film of left lateral for patient.

was used for dose calculations available in the Eclipse TPS. A TBI-specific 10MV photon beam machine has been used for this purpose. It is necessary to use a low-dose rate to decrease the probability of interstitial pneumonia. The dose rate used in TBI was $7.5 \mathrm{cGy} /$ min in a $400 \mathrm{~cm}$ SSD. The skin dose was increased using a bilateral spoiler ( $1 \mathrm{~cm}$ thickness) covering the whole body and is placed approximately $10 \mathrm{~cm}$ from the patient for two techniques.

Twenty TBI patients who were treated with the bilateral technique and planning method described above between June 2017 and December 2018 also underwent AP-PA TBI planning. All patients were acute lymphoblastic leukemia. Mean age was 23 years old. 5 patients were child. 14 patients were male and 6 patients were female. The mean doses of

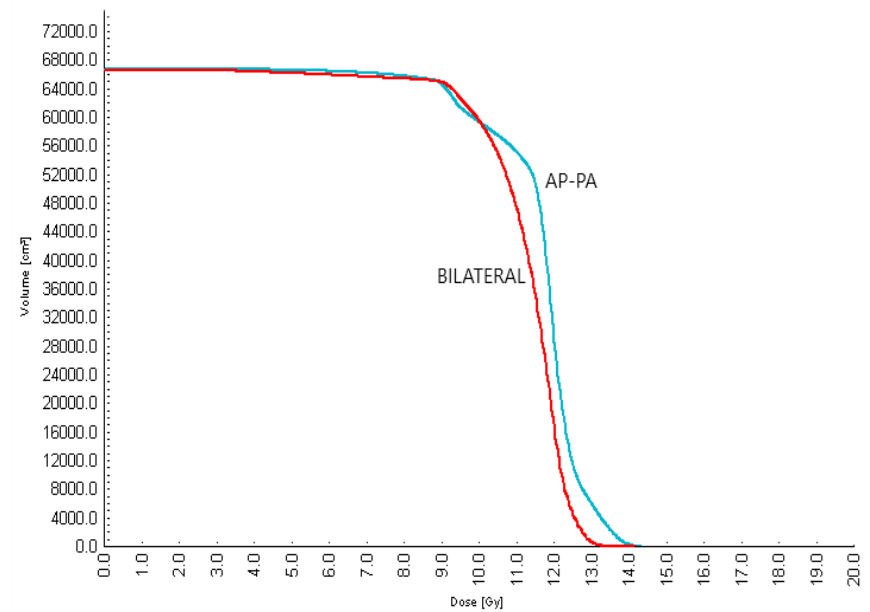

Figure 3. Comparison of the DVH for an irradiated whole body with AP-PA and bilateral technique.

thyroid, lung, kidney, liver, whole body and treatment volumes and the maximum doses of $2 \%$ volumes (D2) were calculated from the dose volume histogram and transferred to the SPSS file. The non-parametric Wilcoxon test was used to compare the dose values for two techniques.

\section{RESULTS}

In present study, to evaluate the doses of organs at risk, the two TBI treatment techniques were compared using the Eclipse TPS and using dose volume histograms (DVH). A comparison between the dose volume histograms of two techniques are shown in Figure 3-8. The mean body volume of the treated patients was $48.7 \mathrm{~m}^{3}\left(14.8-89.2 \mathrm{~m}^{3}\right)$. Table 1 was created using graphs 3-8.

As a considering table 1 , the thyroid gland mean

Table 1. Statistical analysis of DVH of two techniques (Mean \pm sd)

\begin{tabular}{llll}
\hline Parameters & Lateral & AP-PA & p value \\
\hline TD2 & $12.78 \pm 1.26$ & $13.01 \pm 0.35$ & .478 \\
Tmean & $11.95 \pm 1.04$ & $12.64 \pm 0.44$ & .021 \\
PD2 & $10.99 \pm 0.68$ & $10.71 \pm 0.27$ & .142 \\
Pmean & $9.39 \pm 0.99$ & $9.61 \pm 0.2$ & .614 \\
LD2 & $12.90 \pm 0.7$ & $12.60 \pm 0.21$ & .032 \\
Lmean & $11.05 \pm 0.54$ & $11.51 \pm 0.33$ & .002 \\
KD2 & $12.49 \pm 0.6$ & $12.59 \pm 0.29$ & .169 \\
Kmean & $11.66 \pm 0.94$ & $12.36 \pm 0.32$ & .004 \\
Maxdose & $14.54 \pm 1.26$ & $14.40 \pm 0.35$ & .896 \\
BodyD2 & $13.06 \pm 0.37$ & $13.52 \pm 0.31$ & .0001 \\
BodyDmean & $11.49 \pm 0.35$ & $11.69 \pm 0.34$ &
\end{tabular}

T: thyroid, P: lung, L: liver, K: Kidney, D2: volume of received 2\% of total dose, Mean: Mean dose, Max: maximum, Body: Total target volume, AP-PA: anteroposterior 


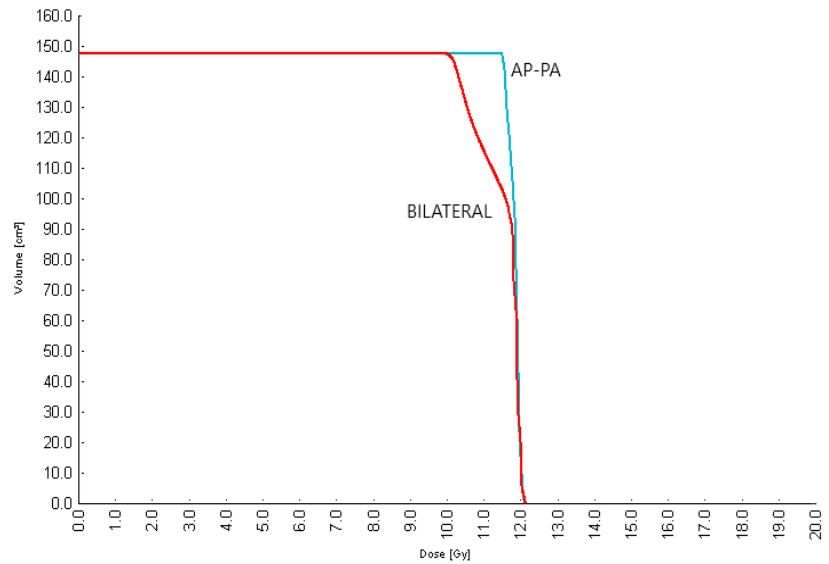

Figure 4. Comparison of the DVH for left kidney with AP-PA and bilateral technique.

doses were significantly lower in lateral technique (11.98 and $12.64 \mathrm{~Gy}, \mathrm{p}=0.21$ ). It was observed no statistically dose difference between the two techniques in terms of lung doses. Since, lung were protected via lead blocks in both of two techniques. Generally, it is recommended that the lungs to receive $80 \%$ of the prescribed dose (10). In present study, the mean dose of lungs were almostly 9.6 Gy $(80 \%$ of the prescribed dose) in both techniques. The mean doses of liver and kidney were lower in the bilateral TBI technique ( $p=0.002$ and $p=0.004$, respectively) (Table 1). D2 doses of liver were lower in favor of AP-

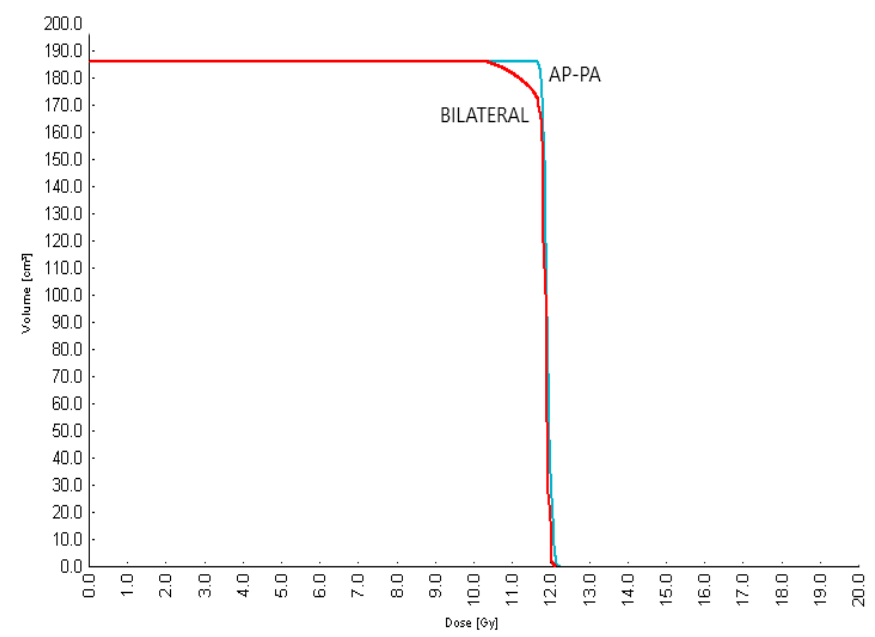

Figure 5. Comparison of the DVH for right kidney with AP-PA and bilateral technique.

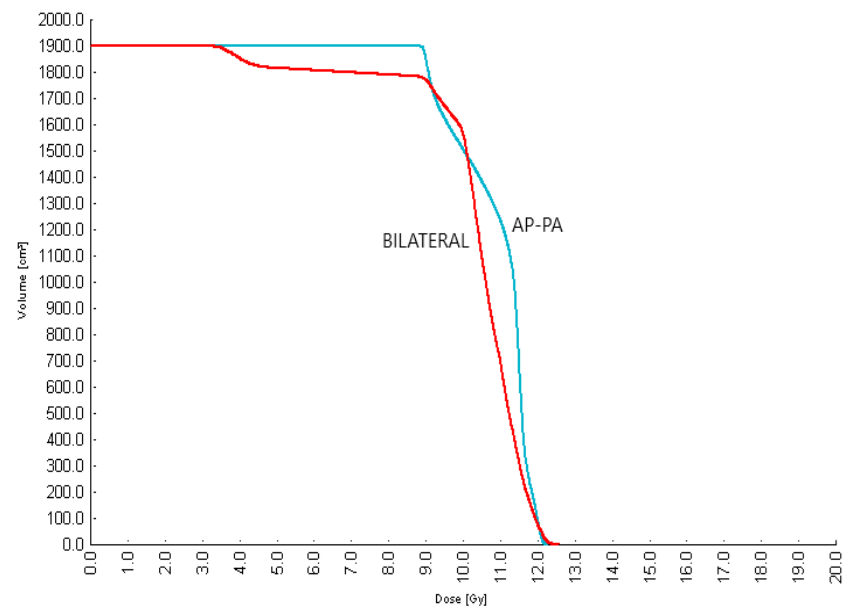

Figure 6. Comparison of the DVH for liver with AP$\mathrm{PA}$ and bilateral technique.

PA planning technique ( $p=0.032)$. In comparison of the hot points between the two techniques, the bilateral position was significantly superior $(p<0.0001)$ (Table 1). It was observed no statistically dose difference between the two techniques in terms of mean doses of body (12.60 and $12.90 \mathrm{~Gy}, \mathrm{p}=0.003)$.

\section{DISCUSSION}

The main reason for the difference of the thyroid gland mean doses was the availability of compensator use for neck in the lateral technique. AP-PA position is not suitable for compensator use. As a consequence of this situation, the hot points increase in the neck region. Since, the same dose is given at the same time

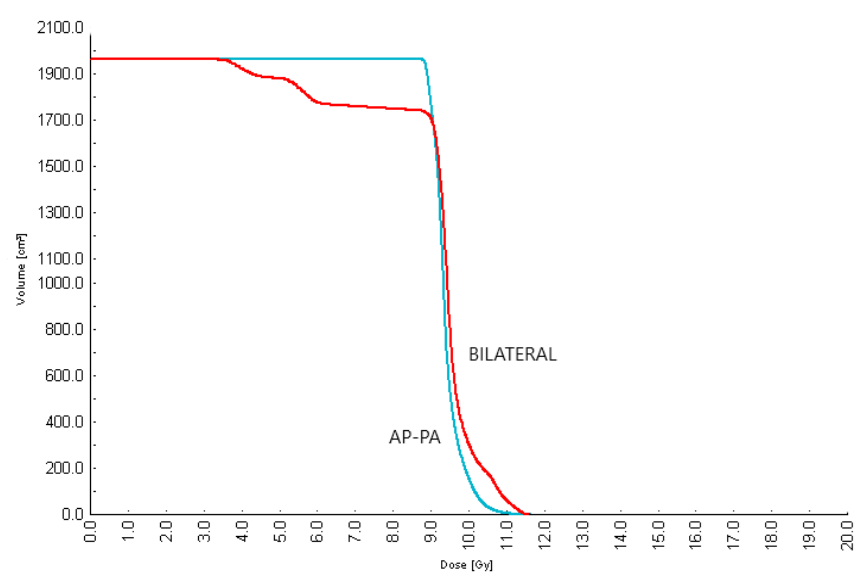

Figure 7. Comparison of the DVH for lung with AP$\mathrm{PA}$ and bilateral technique. 


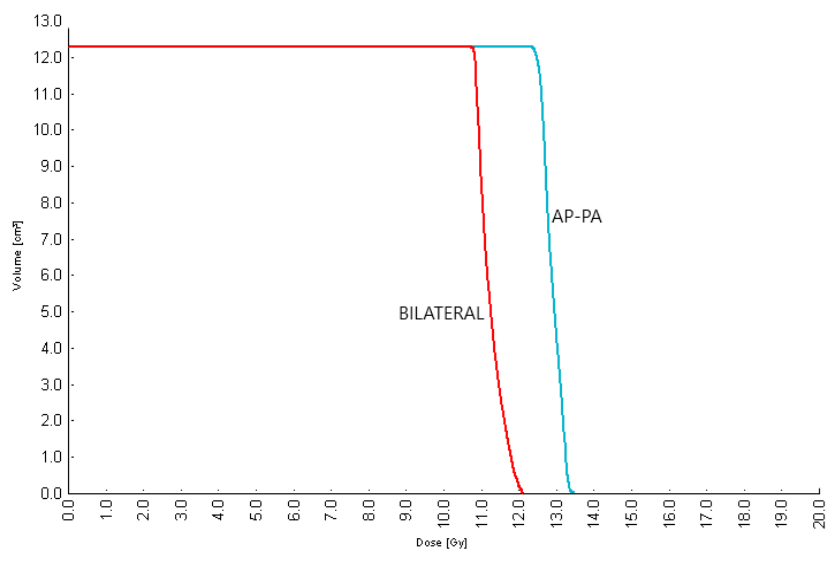

Figure 8. Comparison of the DVH for thyroid with AP-PA and bilateral technique.

for the neck and body regardless of their thickness. The incidence of hypothyroidism after TBI is ranging from $6.5 \%$ to $73 \%(5-9)$. However, the mean dose difference between the treatment techniques does not effect the incidence of hypothyroidism, thyroiditis and Basedow disease. Since, the prescribed doses for $\mathrm{TBI}$ are relatively lower than other radiotherapy plans (5). While lungs were shielded for a daily one fraction dose during the bilateral irradiation, in AP-PA technique, lungs were shielded for a daily two fraction dose. Because, the arm thickness decreased the lung dose in the bilateral technique. However, in APPA technique, the thickness of the arm did not help in decreasing the lung dose. Tomas et al reported bilateral position superior than AP-PA position for pulmonary complications in TBI patients at their multivariate analysis in 478 patients $(14 \%$ and $27 \%$, $\mathrm{p}=0.02)(5)$.

Hepatocytes response to radiation similar like lateresponding tissues (alpha/beta ratio 1-2) (11). In this regard, sinusoidal obstructive syndrome development risk after $\mathrm{TBI}$ can be reduced with fractionated treatments (12). Some transplantation programs offer blocking of kidneys to reduce nephropathy risk if the doses exceed 12 Gy (13). However, blocking kidney is not feasible, so not routinely used. In our study, the mean kidney doses were above the 12 Gy in AP-PA position. These should be considered when AP-PA technique is chosen for TBI. According to most TBI protocols, midline (umbilicus) and organ doses should not exceed $\pm 10 \%$ of the prescribed dose (1416). While the maximum dose remained within $\pm 10 \%$ in the bilateral technique, the maximum dose in the
AP-PA technique was not within the limits. In present study, it was observed that the lateral position was superior to the AP-PA position in order to prevent the hot spots. This is due to the more uniform structure of the body in the lateral position and the body irregularities can be corrected with compensators. In the AP-PA position, it is more difficult to tolerate the body irregularities. Additionally, when comparing the dose distributions of the abdominal organs (liver, kidney), it was seen that the results were statistically better in the bilateral position. The bilateral position provides an advantage in terms of more homogenous dose distribution and better quality planning.

It was increased confidence in determining the dose in any point of the patient using TPS. Most treatment planning systems do not allow to calculate the dose of patients at an extended source-surface distance (SSD). There is a limited number of publications in the literature of special treatment planning systems developed for $\mathrm{TBI}(4,17)$. Use of the treatment planning system and special compensators allowed us to make the dose more uniform in the patient's body. Additional advantages to this aproach include the ability to treat patients while they are supine, which is both more comfortable. Standing for long periods of time can be quite difficult for patients who are usually ill and tired. This technique is especially useful in pediatric patients under anesthesia. In this study, the dose distributions were calculated for AP-PA and bilateral opposed techniques at extended SSD using TPS. As a result, both treatment techniques can be safely used for the TBI. However, the results showed a more homogeneous dose distribution for the bilateral TBI technique. Additionally, when comparing the dose distributions of the organs (liver, kidney, thyroid), it was seen that the results were statistically better in the lateral position. This shows that bilateral TBI technique would be suitable for clinical purposes. In addition, dose volume histograms are the most effective way of modifying treatment techniques to reduce acute and prolonged radiation-related toxicity. In the future, it will be more useful to increase the use of treatment planning systems for TBI calculations.

Conflict of interest: Authors declare that there is no conflict of interest between the authors of the article.

Financial conflict of interest: Authors declare that they did not receive any financial support in this study.

Address correspondence to: Serap Catli Dinc Gazi University, Faculty of Medicine, Department of 
Radiation Oncology, Ankara, Turkey

Phone: +903122026594

Cell Phone: +90 5320581181

e mail: serapcatli@hotmail.com

\section{REFERENCES}

1. Van Dyk J, Galvin JM, Glasgow GW, et al. AAP-PAM report No. 17. The physical aspects of total and half body photon irradiation. American Inst Phys: New York; 1986.

2. F.M.Khan. The physics of radiation therAP-PAhy, 4th Edition, Lippincott Williams and Wilkins, Philadelphia 2009; p.405.

3. Sourati A, Ameri A, Malekzadeh M. Acute side effects of radiation therAP-PAy 2017.

4. Abraham D, Colussi V, Shina D, et al. TBI treatment planning using the adac pinnacle treatment planning system. Medical Dosimetry 2000;25,4:219-24.

5. Thomas O, Mahe M, Campion L, et al. Longterm complications of total body irradiation in adults. Int J Radiat Oncol Biol Phys 2001;49:125-31.

6. Tamura K, Shimaoka K, Friedman M. Thyroid abnormalities associated with treatment of malignant lymphoma. Cancer 1981;47(11):2704-11.

7. Paulino A, Wen B, Brown C, et al. Late effects in children treated with radiation therAP-PAy for wilms' Tumor. International Journal of Radiation Oncology, Biology, Physics 2000;46,5:1239-46.

8. Stuart AL, Clark DJ, Wallace WH, et al. Endocrine deficit after fractionated total body irradiations. Arch Dis Child. 1992; 67(9):1107-10.

9. Sklar CA, Kim TH, Ramsay NKC. Thyroid dysfunction among long-term survivors of bone marrow transplantation. Am J
Med 1982; 73: 688-94

10. Quast U. Whole body radiotherAP-PAhy: A TBI-guideline J Med Phys 2006;31(1):5-12.

11. Fisher DR, Hendry JH. Dose fractionation and hepatocyte clonogens: Alpha/beta congruent to 1-2 Gy, and beta decreases with increasing delay before assay. Radiat Res 1988;113(1):51-7.

12. Thomas ED, Clift RA, Hersman J, et al. Marrow transplantation for acute nonlymphoblastic leukemic in first remission using fractionated or singledose irradiation. Int J Radiat Oncol Biol Phys 1982;8(5):817-21.

13. Lawton CA, Cohen EP, Murray KJ, et al. Long-term results of selective renal shielding in patients undergoing total body irradiation in preparation for bone marrow transplantation. Bone Marrow Transplant 1997;20(12):1069-74.

14. Gunderson T. Clinical Radiation Oncology. J.B. Lippincott Ed 2003;126-56.

15. Sanchez, F, Quast U, Arrans R, et al. Reporting total body irradiation prior to bone marrow transplantation. European group for blood and marrow transplantation (EBMT) 1992;36126.

16. Podgorsak EB. Radiation oncology physics: A handbook for teachers and students, International Atomic Energy Agency 2005;224-86.

17. Lavallee M, Aubin S, Larochelle M, et al. 3D heterogeneous dose distrubutions for total body irradiation patients. Journal of AP-PAplied Clinical Medical Physics 2011;12,3. 